\title{
Observations on the Flora of Japan.
}

\author{
(Continued from p. 60.)
}

\section{By}

\author{
'T. Makino. \\ Lecturer of Botany in the Science College, \\ Imperial University, Tokyo.
}

Enkianthus perulatus C. Schneider, Ill. Handb. Laubholzk. II. (1912), p. 520, fig. $340 \mathrm{~g}$. = E. perulatus Makino in Bot. Mag., Tokyo, XXVII. (1913), p. 21.

Euonymus Chibai Makino, sp. nov. (Fig. I.)

A sempervirent tree, glabrous ; branches terete, viridescent, verruculose with fuscous striped-punctate lenticels below, slightly 4-striate, often hardly swelling at nodes; branchlets opposite, erect-patent, 4-striate, viridescent. Leaves dense, opposite, petiolate, oval or elliptical, abruptly acuminate with an obtuse tip at the apex, acute at the base, crispato-crenate except the entire lower half, narrowly marginate on margin, coriaceo-chartaceous, green and lucid above, yellowish-viridescent beneath, $5-12 \mathrm{~cm}$. long, $3-6 \frac{1}{2} \mathrm{~cm}$. wide, remain on tree during 3 years ; midrib slender, prominent on both surfaces; veins about 6-9, delicately prominent on both surfaces when dry, erectpatent, arcuate upwards, connecting each other near the margin; veinlets loosely reticulated; petiole erect-patent or spreading, green, canaliculated in front, $8-15 \mathrm{~mm}$. long. Cymes appear at the leafless axil in the basal portion of the branchlets of this year, few to several flowered, long-peduncled, dichasial, viridescent; peduncle $17-46 \mathrm{~mm}$. long in fruit, erect-patent, compressed-4-angled; branches erect-patent, articulated to the top of the peduncle, 1-2-articulated, 4-angled; extreme pedicels 5-7 mm. long in fruit, shorter than the capsule. Capsule 
about 1-5 to a cyme, large, pendulous, with a 4-lobate persistent viridescent calyx $\left(3-4 \frac{1}{2} \mathrm{~mm}\right.$. in diameter) at the base, acutely quadrangular and broadly turbinate, subtruncate and slightly concave in centre at the apex, broadly obtuse and hardly projecting at the base, shallowly 1-grooved longitudinally in the faces, glabrous, eggyellow, subsmooth, glabrous, of ten scarcely spreadingly subrugose, 4- or very rarely 5 -celled, 12-20

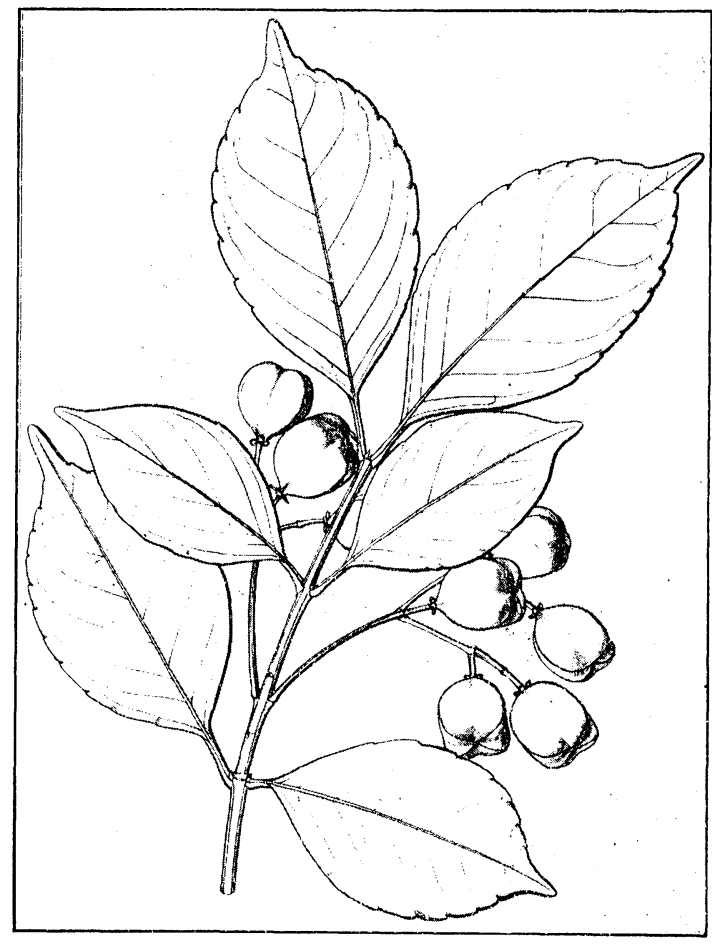

Fig. I. reduced.

$\mathrm{mm}$. long, 11-16 mm. across, dehiscing loculicidally; carpels thickly coriaceous, septiferous and placentiferous. Seeds usually 2 to each cell, one above and one below and closely placed each other, globose, nearly smooth, with a dorsal line, isabelcoloured; about $5-5 \frac{1}{2} \mathrm{~mm}$. across ; aril entirely covering, orangecoloured; albumen pale, fleshy and oily; embryo green ; cotyledons flat, orbicular, about $3 \frac{1}{2} \mathrm{~mm}$. broad; hypocotyl minute, oblong, obtuse at the end; testa thin but crustaceous.

Nom. Jap. Hizen-mayumi (nov.).

Hab. Prov. HIZEN : Shiroyama in Isahaya, silvan place on hill (Tsunesaburô Chiba! Jan. 7, 1906 ; Zentarô Tashiro! Dec. 3, 1911; Tomitarô Makino! Aug. 1908).

The tallest one among the evergreen Euonymus of Japan. I have named this species in honour of Mr. Tsunesaburô Chiba, who first found it and kindly sent me the specimens. 
Hamamelis incarnata Makino, sp. nov.

A deciduous shrub, divided from the base, erect, ramose, grey-umber, dispersed with old lenticels; branches slender, covered with grey-sooty bark, thinly dispersed with minute lenticels, terete, glabrate, flexuous; branchlets tomentose with short stellate dark hairs towards the apex; bud lanceolatooblong, obtuse, compressed, densely tomentose (tomentum darkish in caducous stipules, which are covering and protecting the young leaves, and avellaneous in very young leaves of the bud). Leaves...... Inflorescences appear through or towards the top of the branchlets of last year, loosely or subdensely disposed. Flowers solitary or closely binate at the top of the peduncle, cernuous, yellowish-flesh-coloured, but deeper-fleshcoloured towards the base, with a fishy smell, about $3 \frac{1}{2} \mathrm{~cm}$. across; feduncle terete, curved downwards, virid-umber, tomentose with minute stellate hairs as are the bracts and bracteoles, slightly enlarged above, about $8-1.0 \mathrm{~mm}$. long, with a node below; bracts, 2, opposite, erect-patent, semiorbicular, rounded at the apex, entire, concave, glabrous internally, subcoriaceous, darkviridescent, about $2-3 \mathrm{~mm}$. long ; bracteoles 2 , opposite, alternate with the bracts, to which they are closely appressed and equal or scarcely longer in length, appressed to the calyx, erectpatent, semiorbicular, rounded at the apex, entire, ciliated, concave and purpurascent internally, connate on one side forming a cupule, thinner than the bracts and chartaceous. Calyx appressedly subtended by the bracteoles and bracts, from which it is much exserted, deeply 4-parted, about 5-6 $\mathrm{mm}$. long, about $9-10 \mathrm{~mm}$. across the lobes, tomentose with very minute stellate umber hairs externally, glabrous subshining and deeppurple internally, persistent; tube very short, shallowly patelliform, adherent to the ovary below; segments 4, 2-seriate, spreading and at length revolute, elliptical, obtuse at the apex, entire, subcoriaceous, ciliated on margin, tomentose at the apex internally, about $4 \frac{1}{2} \mathrm{~mm}$. long, $3-3 \frac{1}{2} \mathrm{~mm}$. broad. Petals 4 , inserted at the throat, sessile, spreading and finally reflexed, but circinate in bud, alternate with the calyx-segments, elongate, linear, strap-shaped, entire, unequally bifid at the apex 
(lobes oval to oblong, obtuse at the apex), cuneately attenuated at the base, membranaceous, corrugato-undulate, glabrous, delicately several-veined longitudinally, about $2 \mathrm{~cm}$. long, $2-2 \frac{1}{2}$ $\mathrm{mm}$. wide, deciduous. Stamens 4 , alternate with petals, inserted at the throat, erect-patent, about one-half as long as the calyx, glabrous, about $2 \mathrm{~mm}$. long; filament straight, stout, thick, smooth, compressed antero-posteriorly, deep-purple; anther 2-celled, introrse, rounded, emarginate at the apex, purple but deep-purple in the connective, widely and orbicularly opening by the elliptical persistent lids, which each is fixed to the inner side of each anther-cell, $1 \mathrm{~mm}$. long, with yellow pollen. Glands 4, alternate with the stamens and each stands between them, much smaller than the stamens, opposite to the petals and closely stand before them, erect-patent, curved dorsally, liguliform, obtuse truncate or retuse at the apex, scarcely enlarged below, entire, thickish, convex in front, plane in back, glabrous, smooth, deep-purple, about $1 \frac{2}{5 m}$. long, secreting honey. Pistil slightly lower than the stamens, erect, adherent to the lower portion of the calyx-tube at the base, surrounding by the inconspicuous annular disk of the inner side of the calyxtube, about $2 \frac{1}{2} \mathrm{~mm}$. long; ovaries 2 , connate at the base, erect, hirsute with adpressed light-fulvous stellate hairs, shortly ovate, one-celled, thick-walled, with 1 globular ovule; styles recurvoerect-patent, continued to ovary, thick, stout, somewhat compressed antero-posteriorly, slightly one-canaliculated ventrally, gradually attenuated above, glabrous, deep-purple; stigma terminal, not thick. Fruit......

Nom. Jap. Akabana-mansaku.

Hab. Prov. MUSASHI: Tokyo, cultivated (K. Onda! March 1912 ; T. MAK INo! March 1913).

This species is very remarkable by its reddish flowers instead of having yellow ones as in all other species such as $H$. virginiana Linn., $H$. japonica Sieb. ET Zucc. and $H$. mollis OLIV.

Eurya yakushimensis Makino, nom. nov. 
Eurya japonica var. yakushimensis Makino in Bot. Mag., Tokyo, XXIV. (1910), p. 20.

Nom. Jap. Hime-hisakaki.

Hab. Prov. ÔSUMI : Isl. Yaku-shima ('T. Makino! Sept. 1909).

Elæagnus Matsunoana Makino, sp. nov.

A shrub or small tree, deciduous, densely ramose; branches dark-brown; branchlets alternate, terete, depressedly leprous with grey or darkish-avellaneous scurfs; young branchlets divaricate, depressedly densely leprous with pale-gilvous scurfs. Leaves alternate, petiolate, oblong or oblong-lanceolate, shortly acuminate with an obtuse point at the apex, rounded or rarely acute and often slightly unequal-sided at the base, entire and ciliated with stellate hairs, membranaceous, light green and thinly dispersed with stellato-fasciculate erect hairs above, depressedly densely covered with silvery scurfs mixed with gilvous stellate hairs, which are denser and deeper-coloured and soft to touch in the young leaves, about $2-8 \mathrm{~cm}$. long, $1-3 \mathrm{~cm}$. wide; midrib prominent beneath; veins delicate, about $6-7$ on each side, erect-patent, arcuate upwards; veinlets inconspicuous; petiole $2-6 \mathrm{~mm}$. long, densely covered with scurfs mixed with stellate hairs. Flowers........ Fruit small, pedicellate, oval when young, mucronately beaked at the top, densely covered with depressed fuliginous scurfs; pedicel axillary, solitary, gracile, gradually more or less enlarged above, densely and depressedly covered with silvery scurfs, about $2-3 \frac{3}{4} \mathrm{~cm}$. long.

Nom. Jap. Hakone-gumi (nov.).

Hab. Prov. SAGAMI: Mt. Futago in Hakone (T. Makino! June 16, 1912).

The nearest ally of this species is Elæagnus umbellata THunb., from which it differs by having the erect stellato-fasciculate hairs (not depressed scurfs) on the upper surface of leaves, and many stellate hairs on the under surface of leaves, and the solitary pedicel in the axil. It is also different from E. Yoshinoi Makino, a good species, which has the broader 
tomentose and not silvery leaves, and tomentose fulvous branchlets. I have named this new species in memory of $\mathrm{Mr}$. DyûTarô Matsuno, professor of Natural History in the First Middle School of Kanagawa Prefecture, who collected this plant in an excursion with me in the above-cited locality.

Elæagnus montana MAKino, sp. nov.

A shrub, deciduous, densely ramose; branches dark-brown, terete, depressedly leprous with old scurfs; branchlets alternate, erect-patent, densely covered with depressed dark-ferruginous scurfs, angulate, often flexuous. Leaves alternate, petiolate, elliptical, oblong or oblong-lanceolate, subabruptly acuminate with an obtuse tip or obtuse at the apex, acute or subobtuse at the base, entire, green and thinly dispersed with pale depressed scurfs above, silvery with dense depressed scurfs sometimes thinly mixed with ferruginous scurfs beneath, chartaceous, $3-8 \frac{1}{2} \mathrm{~cm}$. long, $1 \frac{1}{2}-4 \mathrm{~cm}$. broad; midrib prominent beneath; veins about 6-9 on each side, erect-patent, delicate; veinlets inconspicuous. Flowers usually solitary, but sometimes 2-3fasciculate, pedicellate, axillary, cernuous, about $11 \mathrm{~mm}$. long ; pedicel shorter than the flower, gracile, about $10 \mathrm{~mm}$. or less long, covered with silvery and gilvous depressed scurfs. Calyx denseiy covered with silvery depressed scurfs thinly mixed with gilvous scurfs outside; limbs 4, patent, shorter than the tube, broadly ovate, acute, thinly covered with scurfs inside; tube oblong-cylindrical; calyx-base small, fusiform, about $2 \mathrm{~mm}$. long. Stamens 4, slightly exserted; anther oblong-lanceolate, acute at the apex, bifid at the base. Style exserted, filiform, hooked at the top, glabrous, stigmatose on one side above. Fruit, erect, with a strict pedicel, oval-ellipsoid, covered with depressed castaneo-atropurpureous scurfs, about $9-11 \mathrm{~mm}$. long, red; pedicel somewhat enlarged above, $10-15 \mathrm{~mm}$. long.

Nom. Jap. Mame-gumi.

$H a b$. JAPAN, high mountains.

An intermediate species between Elæagnus multiflora Thuns. and E. umbellata Thunb. 
IlexiMutchagara Makino, sp. nov. (Fig. II. A.)

Ilex crenata Ito et Matsum. Tent. F1. Lutch. in Journ. Sc. Coll. Imp. Univ. Tokyo, XII. (1899), p. 367, non Thunb.

Ilex crenata Matsum. Ind. Pl. Jap. II. 2 (1912), p. 314, pro parte, non Thunв.

Ilex crenata forma $\%$ genuina Loesener, Monogr. Aquifol. (1901), p. 201, pro parte.

A shrub, sempervirent, densely ramose; branches terete, striate, glabrous; branchlets erect.patent, slender, sulcatostriate, viridescent, glabrous or minutely pubcrulent in the sulci. Leaves dense, shortly petiolate, oblancedate to obovato-oblong, or narrowly oblong, obtuse or emarginato-obtuse at the apex, cuneate towards the base, subregularly or irregularly crenato-serrate or sometimes sharply serrate except the entire base, narrowly marginate on margin, lucid and green above, paler and often very thinly brownis h-puncticulate under lens beneath, coriaceous or chartaceo-coriaceous, glabrous, $2 \frac{1}{2}-6 \frac{1}{2} \mathrm{~cm}$. long, 9-26 mm. wide, usually darkish in the upper surface when dry; nervation inconspicuous ; midrib

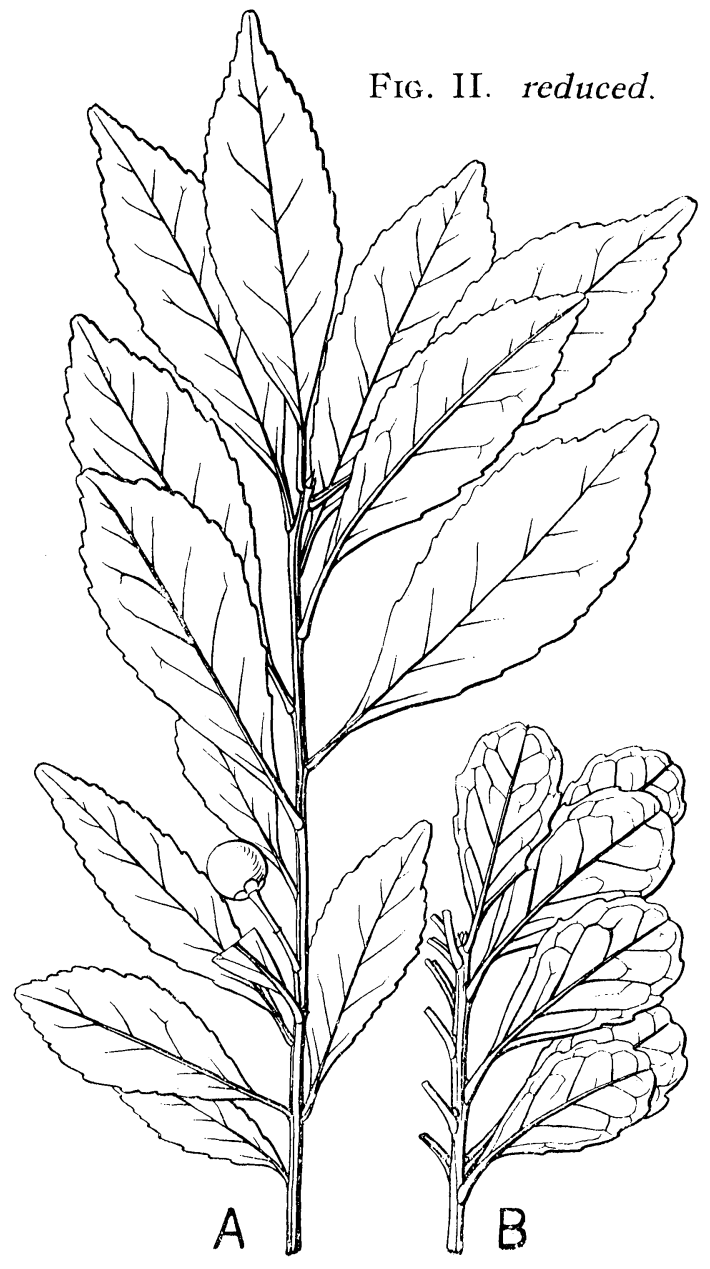


prominent beneath, canaliculato-impressed above; veins loose, about $4-7$ on each side, scarcely visible or nearly invisible, erect-patent, straight or arcuate downwards or upwards; veinlets invisible; petiole semiterete, canaliculated in front, often very minutely puberulent, 2-8 $\mathrm{mm}$. long. Cyme (male) small, much shorter than leaves, fasciculate on a branchlets shortened or alternate on a small branchlets (of this year) lengthened, often 3-flowered or 1-flowered, about $11 \mathrm{~mm}$. or less long; peduncle gracile, minutely puberulent, about $3-7 \mathrm{~mm}$. long; pedicels minutely subpuberulent, about $2-3 \frac{1}{2} \mathrm{~mm}$. long; bracts and bracteoles minute, deltoid or deltoid-subulate. Flowers (male) small, 4-merous. Calyx-lobes semiorbiculate, concave, very minutely ciliolated below. Petals oval. Stamens glabrous; filament very short; anther elliptical, deeply bifid at the base. Rudimentary pistil minute. Drupe globose, solitary, with a persistent calyx at the base, black when mature, glabrous, smooth, about $7-8 \mathrm{~mm}$. across ; pedicel axillary, solitary, strict, gradually enlarged towards the fruit, 2-bracteate in the middle, minutely puberulent, about $9-15 \mathrm{~mm}$. long; bracts subulate. Pyrenæ oval-elliptical, 3-angulate, yellowish, smooth, thin, coriaceous, about $5 \mathrm{~mm}$. long.

Nom. Jap. Mutchâgara (vernacular), Shima-inutsuge ( $T$. MaKino).

Hab. LIUKIU: Kunchan in Isl. Okinawa (Y. TASHIRo! herb. Sc. Coll. Imp. Univ. Tokyo, May 1887; J. Matsumura! herb. ibid. May 1897), Between Onna and Nago in Kunchan, Isl. Okinawa (S. Tanaka! herb. ibid. May 16, 1891), Mt. Nago in Isl. Okinawa (G. Nakahara! herb. ibid. April 1907; S. Yajima! herb. ibid. Jan. 19, 1911), Mt. Onna in Isl. Okinawa (S. Kanagusuku! July 1910), Isl. Kume (H. Kuroiwa! April 1898); YAYEYAMA ARCHIP. : Isl. Iriomote (S. TANAKA! herb. ibid. June 15-19, 1891).

This species is very closely allied to Ilex crenata Thunb., but in the latter the branchlets are less sulcato-striate, and leaves are usually smaller and thicker, more numerously and conspicuously punctate beneath, mucronate-tipped at the apex, 
more sharply serrate, subobtusely cuneate or acute towards the base, not dark when dry.

Ilex crenata Thunb. Fl. Jap. (1784), p. 78.

var. Fukasawana Makino, var. nov.

A shrub, sempervirent, densely ramose; branches terete, glabrous, grey or grey-drab, often subverruculose with pale lenticels; branchlets green, subsulcato-angulate, minutely puberulent. Leaves dense, shortly petiolate, oblong or angustately oblong, mucronato-obtuse at the apex, acute at the base, depressed-crenate, angustately marginate on edges, green and lucid above, paler and thinly minutely punctate beneath, coriaceo-chartaceous or chartaceous, $2-4 \frac{1}{2} \mathrm{~cm}$. $10 \mathrm{ng}, \frac{3}{4}-2 \mathrm{~cm}$. broad; midrib prominent beneath; veins inconspicuous; petiole $2 \frac{1}{2}-5 \mathrm{~mm}$. long, minutely puberulent. Drupe solitary, globose, obscurely 3-sided when young, about $7 \mathrm{~mm}$. across, glabrous, smooth, with a persistent semiorbiculately lobed calyx at the base; pedicel gracile, solitary, axillary, slightly gradually enlarged above, minutely puberulent, $8-14 \mathrm{~mm}$. long, with 2 minute subulate opposite or subopposite or approximate bracts in the middle, viridescent.

Nom. Jap. Tsukushi-inutsuge (nov.).

Hab. Prov. HIGO: Mt. Kakutô-goe ('T. Makino and B. Fukasawa! Aug 1909).

This differs from the type by having the thinner and irregularly more crenate leaves and somewhat 3-sided young drupe. It is especially found in the southern parts of Kiusiu. I have named this in memory of Mr. Buitsu Fukasawa of the Normal School of Kagoshima, prov. Satsuma.

Ilex Matanoana Makino, sp. nov. (Fig. II. B.)

A shrub, sempervirent, densely ramose; branchlets angulatostriate, glabrous. Leaves very dense, small, petiolate, sparse, obovate or oblong-obovate, mucronato- or obtuse-emarginate at the apex, cuneate and entire at the base, few-repand-crenate above, narrowly revoluto-marginate on edges, $8-33 \mathrm{~mm}$. long, 
$5-18 \mathrm{~mm}$. wide, coriaceous, glabrous; midrib prominent beneath ; veins loose, few on each side, delicately prominent and loosely venose beneath; petiole canaliculate in front, glabrous, $1 \frac{1}{2}-8 \mathrm{~mm}$. long. Flower (female) solitary, pedicellate, 4-merous, about $4 \mathrm{~mm}$. in diameter; pedicels 1-2-fasciculate in the axil of leaves, much shorter than leaves, about $4 \mathrm{~mm}$. or less long, strict, glabrous, minutely bracteate at the base. Calyx-lobes semiorbicular. Petals oval, concave, ciliolated. Stamens (rudimental) higher than the ovary; anther oval-deltoid, shorter than the filament. Ovary globose, $1 \frac{1}{2} \mathrm{~mm}$. across, glabrous, with a sessile stigma at the top.

Nom. Jap. Munin-inutsuge (nov.).

Hab. OGASAWARA ISL. = BONIN ISL. (Herb.! Mus. Imp. Tokyo, 1879).

I have named this novelty in dedication to Mr. Migaki Matano, Director of the Imperial Museum, Tokyo.

Ilex Sugeroki Maxim. in Mém. Acad. Imp. Sc. St. Pétersb. 7. sér. XXIX. n. 3 (1881), p. 22 et 35.

subsp. a. brevipedunculata (Maxim.) Makino.

Ilex Sugeroki forma brevipedunculata Maxim. 1.c. p. 36 tab. 1, fig. d, e ; Loesener, Monogr. Aquifol. p. 134.

A shrub, densely ramose. Leaves very dense, smaller. Peduncle short.

Nom. Jap. Akami-no-inutsuge (K. MiYaBE), Aka-tsuge (J. Matsumura), Miyama-kurosoyogo (T. Makino).

Hab. JAPAN.

This is always found growing in high and alpine mountains, and abundant in the northern Japan.

subsp. b. longepedunculata (Maxim.) Makino.

Ilex Sugeroki forma longepedunculata Maxim. 1. c. tab. 1, fig. 7, excl. d, e.; Loesener, 1. c.

A small tree, sempervirent, laxly ramose, rather loosely foliose; branches slender, terete, ramurose, glabrate, castaneofuliginous, very thinly dispersed with minute lenticels; branchlets erect-patent, alternate, slender, puberulent with short-patent 
hairs. Leaves coriaceous, alternate, petiolate, ovato-elliptical to lanceolato-oblong, or elliptical, shortly acuminate with an obtuse tip, obtuse or acutish at the base, adpressed-serrate with few to several teeth from the middle or below the middle to the apex, rarely mixed with the nearly entire ones, glabrous, but in young leaves puberulent on the midrib on the upper surface, shining and deep-green above, paler beneath, about $2 \frac{1}{2}-5 \mathrm{~cm}$. long, $1 \frac{1}{2}-2 \frac{1}{2} \mathrm{~cm}$. broad; midrib prominent above ; veins erect-patent, about $6-10$ on each side, delicately prominent above when dried; veinlets invisible; petiole $3-8 \mathrm{~mm}$. long, semiterete, canaliculated in front, puberulent with short patent hairs and the hairs finally almost fallen off. Drupe red, erect, solitary, peduncled, small, globose, glabrous, smooth, mucronate with a depressed stigma at the top, with a persistent ciliated-semiorbiculato-4-lobed calyx at the base, about 5-6 $\mathrm{mm}$. across; peduncle about equalling the leaves in length, solitary, axillary, erect-patent, gracile, glabrous, $2 \frac{1}{2}-3 \frac{3}{4} \mathrm{~mm}$. long, 2-bracteate above or below the middle; bracts opposite or approximate, minute, adpressed or erect-patent, setaceosubulate, acuminate, ciliated, deciduous, about $2-4 \mathrm{~mm}$. long.

Nom. Jap. Kuro-soyogo.

Hab. Prov. TOSA (T. Makino!), Mt. Shiraga (S. Okamura! April 4, 1906), Mt. Yahazu (R. Yatabe! herb. Sc. Coll. Imp. Univ. Tokyo, Aug. 8, 1888); Prov. KII : Mt. Kôya (J. MatsuMURA and S. Ókubo! herb. ibid. July 19, 1883), Kokuchi-mura (Herb.! ibid. Nov. 14, 1908, with the vernacular name of Abura-ki).

This is a tree, while the a. brevipedunculata is a shrub. It grows on hills and higher mountains in the middle and southern Japan.

Rubus Thunbergii Sieb. ET Zucc. in Abh. Akad. Muench. IV. 2 (1845), p. 126.

var. Harai Makino, var. nov.

Flower double. Otherwise as in the type.

Nom. Jap. Yaezaki-kusaichigo (nov.). 
Hab. Prov. TSUSHIMA (Tomoichirô HaRa! Spring 1910).

Rare. This double-flowered form was found growing wild. I have named this new variety in honour of Mr. TomoICHIRô HARA, who discovered and collected the plant.

Helwingia japonica (Thunb.) Willd. ex F. G. Dietr. Nacht. Gart. Lexc. III. (1817), p. 660 ; A. Diftr. ex Steud. Nomencl. ed. 1., I. (1821), p. 399 ; Naka in Bot. Mag., Tokyo, XVI. (1912), p. 148 (Jap.).

var. parvifolia M'Akino, var. nov.

Branches and branchlets slender. Leaves smaller, orbicular, ovato-orbicular or oval-ovate, abruptly caudato-acuminate at the apex, rounded or subcordate and usually deltoidly shortdecurrent at the base, chartaceo-membranaceous, about $1-5 \mathrm{~cm}$. long, $\frac{1}{2}-3 \frac{1}{4} \mathrm{~cm}$. broad; veins $3-5$ on each side, arcuate upwards, the lower ones closer and spreading and the superior ascending; petiole gracile, $2-20 \mathrm{~mm}$. long. Fruit solitary, attached below the middle of leaves, about $6 \mathrm{~mm}$. across and long.

Nom. Jap. Koba-no-hanaikada (nov.).

Hab. Prov. TOSA : Near Tochinoki in Aki-gôri (T. Makino! June 4, 1892).

Eupatorium japonicum Thuns. var. tripartitum Makino in Bot. Mag., Tokyo, XXIII. (1909), p. 142.

forma angustatum MaKino, nov.

Leaf-segments linear-lanceolate, acuminate, sharply dentate; lateral segments much smaller.

Nom. Jap. Hosoba-no-mitsubahiyodoribana (nov.).

Hab. Prov. IDZU : Isl. Hachidzô (S. Tamaki! Aug. 15, 1912).

Fupatorium Lindleyanum DC. Prov. V. (1836), p. 180. var. trifoliolatum Makino, var. nov.

Leaves sessile, trifoliolate, but simple and smaller in those of branches; segments angustate, dentate; middle segment largest, linear-lanceolate, acuto-acuminate at the apex, cuneate- 
ly attenuated and petiolulated at the base; midrib and veins prominent beneath; veins loose, nearly parallel to the midrib; lateral segments much smaller, linear, acute, narrowly cuneate and often shortly petiolulate at the base. Heads usually purpurascent.

Nom. Jap. Mitsuba-sawahiyodori (nov.).

Hab. JAPAN, not uncommon.

Crotalaria sessiliflora Lins. Sp. Pl. ed. 2, p. 1004.

forma a. typica MaKino.

Crotalaria Oldhami MiQ. Prol. Fl. Jap. in Ann. Mus. Bot. Lugd.-Bat. III. (1867), p. 42.

Crotalaria sessiliflora torma obtusata Matsum. in Bot. Mag. Tokyo, XVI. (1902), p. 38.

Leaves lanceolate or oblong-lanceolate.

Nom. Jap. Hiroha-tanukimame.

$H a b$. JAPAN, southern, rather rare.

forma b. eriantha (Sieb. ET Zucc.) Makino.

Crotalaria eriantha SIEB. ET Zucc. in Abhandl. Akad. Muench. IV. 2 (1845), p, 121.

Crotalaria sessiliflora Mig. 1. c.; Franch. et Sav. Enum. Pl. Jap. I. (1875), p. 94, non Linn.

Leaves lanceolato-linear or linear.

Nom. Jap. Tanuki-mame.

Hab. JAPAN, common.

forma c. angustifolia Makino, nov.

Leaves augustato-linear, acuminate, $3-5 \mathrm{~mm}$. broad, $10 \frac{1}{2} \mathrm{~cm}$. or less long.

Nom. Jap. Hosoba-tanukimame (nov.).

Hab. Prov. HIGO (Z. Tashiro! 1912).

(To be continued.) 